GLOBAL JOURNAL OF EDUCATIONAL RESEARCH VOL 15, 2016: 41-47

COPYRIGHTC BACHUDO SCIENCE CO. LTD PRINTED IN NIGERIA. ISSN 1596-6224 www.globaljournalseries.com; Info@globaljournalseries.com

\title{
MANAGING TERTIARY INSTITUTIONS FOR THE PROMOTION OF LIFELONG LEARNING IN CROSS RIVER STATE, NIGERIA
}

ESTHER SAMUEL UKO AND EMEKA SAMUEL NNAJI

(Received 7, July 2015; Revision Accepted 7, October 2015)

\begin{abstract}
The study investigated ways of managing tertiary institutions for the promotion of lifelong learning in Cross River State, Nigeria. One research question was raised and one hypothesis formulated to guide the study. Multistage sampling procedure was adopted for the study. Stratified random sampling technique and simple random sampling techniques were used to draw 400 undergraduate students from a total population of 17,880 undergraduate students in the four tertiary institutions in Cross River State. A researcher's designed instrument with a four point rating scale titled "managing tertiary education for promotion of lifelong learning questionnaire" (MTEPLLQ) was used to elicit responses from the respondents and to collect data. The instrument was face-validated by 3 experts in test and measurement, University of Calabar. A pilot test yielded a reliability coefficient ranging from 0.78 to 0.84. These figures confirmed that the instrument was reliable for use in realizing the research objectives. Mean and standard deviation were used to answer the research question while independent t-test was used to analyze data for the hypothesis tested at.05 level of significance. Results obtained revealed nine strategies that could be adopted by management of tertiary institutions for the promotion of lifelong learning in Cross River State. There was no significant difference in the mean responses of undergraduate students of Federal and State tertiary institutions on the strategies that could be adopted by management of tertiary institutions for promoting lifelong learning in the State. The study concluded that insofar as lifelong learning is concerned, the strategies identified in this study should be adopted by management of tertiary institutions for the promotion of lifelong learning in Cross River State.
\end{abstract}

KEYWORDS: Managing, tertiary institutions, promotion, lifelong learning.

\section{INTRODUCTION}

Education is a deliberate and purposeful activity directed at the achievement of a range of ends which include the development of knowledgeable individuals who are able to think rationally, the formation of a sustainable community and the realization of economic goals benefiting both individuals and their communities (Rizvi \& Lingard 2010). Osaro (2014) stated that education is a major force for the production of population of active citizens in any nation. An active citizen according to Mobala (2012) is someone who is sensitive to and cares about his/her community enough to change it by offering high-level professional expertise in such areas as banking, education, engineering, science, medicine and technology towards the development of the nation for the good of the citizenry.

It therefore implies that active citizenship requires the possession of relevant professional skills and knowledge needed to combat emerging complex problems and challenges facing humanity in the $21^{\text {st }}$ century. However, acquisition of these unique skills and knowledge

Esther Samuel Uko, Department of Educational Administration and Planning, Faculty of Education University of Calabar, Calabar, Nigeria.

Emeka Samuel Nnaji, Department of Educational Administration and Planning, Faculty of Education University of Calabar, Calabar, Nigeria. 
calls for lifelong learning on the part of the citizenry.

Lifelong learning is a gradual and continuous process of acquiring knowledge, skills competencies and attitudes that enable individuals to live, develop and function effectively and efficiently within the society throughout life (Ebirim \& Mbaji, 2012). Lifelong learning according to Aitcheson in Ptbindingsforschm (2014) is a comprehensive and visionary concept which includes formal and non-formal learning extended throughout the life span of an individual to attain the fullest development in personal, social, vocational and professional life. Zuala (2012) submitted that among the objectives of lifelong learning includes active citizenship, employability, social inclusion and personal fulfillment. Lifelong learning stimulates and encourages individuals to acquire skills, knowledge and values that they will require throughout their life time and to apply them creatively in any environment with confidence in all roles. European commission for education and implementation of culture and environment (2002) perceived lifelong education as encompassing all purposeful learning activities whether formal or informal, undertaken on an ongoing basis with the aim of improving knowledge, skills, and competence. It is therefore safe to say that the emphasis of lifelong learning is the ability of individuals to keep learning in different environments, whether formal, informal or non formal for a lifetime.

Formal lifelong learning which is the focus of this study occurs within institutions established primarily to deliver education and learning, often leading to meet established outcomes and qualifications. Knapper and Cropley (2000) maintained that tertiary institutions merit special attention because they have important roles to play in promoting lifelong learning outcomes. The importance is derived from the influence and role of universities and colleges in terms of research and development of theories in different fields of learning. Knapper and Cropley (2000) further stated that what universities teach, investigate and promote influence knowledge, attitudes, values and practices in many areas of the society.

Mbagwu (2013) noted that the more fluid or competitive the society becomes the more challenged individuals desire to acquire new knowledge and skills so that they will not be disadvantaged in their career or profession. Knowledge acquisition is necessary for growth and development of the individual but it diminishes if it is not utilized regularly, hence the need for the promotion of lifelong learning in tertiary institutions. Tertiary institutions in Nigeria offer a range of professional, vocational and general education programmes and courses on both part-time and full-time basis for different levels of degrees such as diploma, bachelor, post-graduate diploma, master and doctor of philosophy.

Osaro (2014) asserted that management of tertiary institutions in the $21^{\text {st }}$ century must aim at promoting and sustaining lifelong learning among Nigerians by attracting people to take up studies in the available programmes and disciplines. Etemeh (2013) advocated that there is need for tertiary institutions' administrators and educational managers to device effective strategies to attract, motivate and retain the teaming population of unskilled, inactive and unemployed citizens in Nigeria in order to enable them develop skills and knowledge that will make them active and functional in the society.

Managing tertiary institutions for the promotion of lifelong learning entails seeking ways to broaden tertiary education and make them serve as centres for social development, economic growth, lifelong manpower development of employable and skilled workers in their work places (Zuala, 2012). This implies that individuals must be given equal opportunities to access tertiary education to learn and achieve appropriate qualifications in their choice of courses offered by tertiary institutions. Even in later life such as retirement, individuals still need to keep learning in order to maintain and remain active citizens whenever and wherever they find themselves.

Etemeh (2013) maintained that promoting lifelong education implies the provision of conditions that will facilitate learning in formal schools considering that each day gives birth to new challenges, problems and discoveries in the field of science and technology which have invariably altered the way in which certain tasks are carried out. Students of tertiary institutions therefore need to be provided with opportunities to upgrade and expand existing skills, acquire new skills to keep them in a better position to face novel challenges in the society and the world over. Osaro (2014) stated that promoting lifelong learning in Nigeria requires giving tertiary educational institutions a facelift in the area of infrastructure and institutional facilities, pedagogy, curricula, general administration and 
manpower. Nwankwo (2014) considered lack of adequate funding as the greatest challenge facing Nigerian tertiary institutions. He further lamented that lack of research facilities and conducive learning environments have been the greatest impediment to life long tertiary education in Nigeria.

Ownwuamanam (2005) added that graduate studies and research are no longer attractive to good graduates that could become prospective university teachers owing to lack of facilities for research and even poor remuneration for teachers in the universities. Akuegwu, Ntukidem, \& Jaja (2011) in a study revealed that availability of information and communications technology (ICT) facilities for quality instructional service delivery in universities is significantly low. While the quota policy has hindered some qualified individuals from gaining admission to study their choice of courses in tertiary institutions, politicization of admission processes has become a major impediment to the promotion of lifelong learning (Osaro, 2014). Okiro (2012) observed that the hunger and quest for knowledge among Nigerian youths is fast decreasing owing in part to the failure of school managers to create the motivation to learn by providing the necessary conditions for teaching and learning to thrive.

The provision of the necessary facilities for teaching and learning is a proven source of motivation for individuals to want to continue to learn and explore the frontiers of knowledge in many fields of learning (Mobola, 2014). Ahymeti (2010) noted that a good library with well stocked up-to-date books, journals, periodicals and efficient information and communication technology (ICT) are essentials that enhance learning. Akuegwu (2014) remarked that provision of ICT facilities in schools will give students ample opportunity to search for information, practice what they have learnt, further explore ideas and topics, interact and actively engage in learning. Zuala (2012) emphasized that lifelong learning could only be encouraged when administrators of tertiary institutions place more emphasis on proper management of personnel (teaching and non teaching staff),prudent management and utilization of funds for the establishment of a motivating teaching and learning environment and introduction of modern pedagogy. Jackson (2013) added that promoting lifelong tertiary education is the only sure way to breakthroughs in the field of sciences, the arts, education and technology to combat many human problems in this twenty first century.

\section{Statement of the problem}

Advancement in technology is fast changing the way tasks are performed in all spheres of human endeavour. Similarly, new social and health problems are emerging. Individuals need to be provided with opportunities to continue to acquire new skills, update and expand existing skills and knowledge in order to face these changes and challenges. This calls for continuous unrelenting learning on the part of Nigerian citizens. Lifelong tertiary education requires reasonable investment in physical facilities, equipment, curricula, staff development and students strength. However, tertiary institutions in Nigeria which serve as formal centres for lifelong education are bedeviled with a lot of challenges ranging from inadequate physical facilities, equipment and lack of general conducive environment for learning and lack of adaptation of academic staff to new patterns and technologies used for disseminating knowledge to students. Consequently, most undergraduates, post-graduate students as well as graduates of tertiary institutions in Nigeria lack requisite skills and competencies needed to solve societal problems. They also lack the zeal and motivation to learn owing to the above mentioned problems. This poor state of Nigerian public tertiary institutions has greatly hampered lifelong learning which is also detrimental to the production of active citizens. It is in the light of the above facts that this study poses a question as to what strategies could be adopted by management of tertiary institutions to promote lifelong learning in Cross River State.

\section{Research question}

What strategies could be adopted by management of tertiary institutions to promote lifelong learning in Cross River State?

\section{Statement of hypothesis}

There is no significant difference in the mean responses of undergraduate students of Federal and State tertiary institutions on the strategies that could be adopted by tertiary institutions in the promotion of lifelong learning in Cross River State. 


\section{Methodology}

The study adopted a survey research design. This study was conducted in Cross River State taking into consideration four tertiary institutions, namely, University of Calabar, Cross River University of Technology, both in Calabar, Cross River College of Education, Akamkpa and Federal College of Education, Obudu.

The population of the study comprised 17,880 undergraduate students drawn from four tertiary institutions. Multistage sampling procedure was adopted for the study. The stratified sampling technique and simple random sampling techniques were used. At the first stage, the tertiary institutions were stratified based on ownership (Federal and State). At the second stage, simple random sampling technique was used to draw 100 undergraduate students from each of the four tertiary institutions under study. This gave a total sample of 400 . A researcher's designed instrument with a four point rating scale titled "managing tertiary education for promotion of lifelong learning questionnaire" (MTIPLLQ) was used to elicit responses from the respondents and to collect data. The instrument had two sections. Section A contained information on the demographic data of respondents while Section B contained information on strategies to be adopted by management of tertiary institutions for promoting lifelong learning.

The instrument was face validated by 3 experts in test and measurement, University of Calabar. A pilot test yielded a reliability coefficient ranging from 0.78 to 0.84 which was deemed well enough for the study. The administration of the instrument was personally carried out by the researcher and three research assistants, the measure yielded $100 \%$ return rate. Mean and standard deviation scores were used in answering the research questions while independent t-test statistics was used to test the hypothesis at 0.05 level of significance.

TABLE 1: Responses on the strategies that could be adopted by tertiary institutions management to promote lifelong learning in tertiary institutions in Cross River State.

\begin{tabular}{lllll}
\hline Items & $\mathrm{N}$ & $\mathrm{X}$ & $\mathrm{SD}$ & Decision \\
\hline Provision of ICT facilities & 400 & 3.92 & 0.30 & Effective \\
Provision of library facilities & 400 & 3.74 & 0.44 & Effective \\
Award of scholarships to hardworking students & 400 & 3.66 & 0.48 & Effective \\
Provision of medical services in schools & 400 & 3.83 & 0.38 & Effective \\
Provision of recreational facilities in schools & 400 & 2.45 & 0.28 & Ineffective \\
Provision of laboratory and workshop facilities & 400 & 3.81 & 0.39 & Effective \\
Provision of conducive classrooms & 400 & 3.60 & 0.50 & Effective \\
Provision of conducive hostel accommodation & 400 & 2.82 & 0.39 & Effective \\
Ensuring effective teaching by academic staff & 400 & 3.42 & 0.50 & Effective \\
Provision of counselling services for students & 400 & 2.74 & 0.47 & Effective \\
\hline
\end{tabular}

Expected Mean $=2.50$

The results in Table I showed the mean responses of undergraduates of the four tertiary institutions on the strategies that could be adopted by tertiary institutions management to promote lifelong learning in tertiary institutions in
Cross River State. A midpoint of 2.5 was adopted as criteria mean. Thus, any mean score that ranged from 2.50 and above was accepted while the mean below 2.50 was rejected. From results presented in the above table, respondents 
accepted that provision of ICT facilities, provision of library facilities, award of scholarships to hardworking students, provision of medical services in schools, provision of laboratory and workshop facilities, provision of conducive classrooms, provision of conducive hostel accommodation, ensuring effective teaching by academic staff and provision of counseling services for students are strategies that could be adopted by tertiary institutions management to promote lifelong learning in tertiary institutions in Cross River State. However, provision of recreational facilities in schools was rated as ineffective in the promotion of lifelong learning by tertiary institutions management. $(X=2.45$, $\mathrm{SD}=0.28)$.

TABLE 2: Independent T-Test analysis of the difference in the responses of undergraduate students of Federal and State tertiary institutions on the strategies that could be adopted by management of tertiary institutions for promoting lifelong learning in tertiary institutions in Cross River State

\begin{tabular}{|c|c|c|c|c|c|c|c|}
\hline Variable & & $\begin{array}{l}\text { Tertiary } \\
\text { Institutions }\end{array}$ & $\mathrm{N}$ & $X$ & SD & $\mathrm{T}$ & Sig. \\
\hline \multirow{3}{*}{$\begin{array}{l}\text { Strategies } \\
\text { promoting } \\
\text { learning }\end{array}$} & & Federal & 200 & 36.70 & 3.14 & \multirow{3}{*}{0.60} & \multirow{3}{*}{0.55} \\
\hline & $\begin{array}{r}\text { for } \\
\text { lifelong }\end{array}$ & & & & & & \\
\hline & & State & 200 & 36.51 & 3.19 & & \\
\hline
\end{tabular}

$$
p>.05 ; d f=398 ; \text { critical } t=1.97
$$

From Table 2, the results showed that calculated $r$-value of 0.60 is less than the critical $r$-value of 1.97 at .05 level of significance with 218 degrees of freedom. With this result the null hypothesis was accepted and the alternate hypothesis rejected. This finding implies that there is no significant difference in the responses of undergraduate students of Federal and State tertiary institutions on the strategies that could be adopted by tertiary institutions management for promoting lifelong learning in Cross River State.

\section{DISCUSSION OF FINDINGS}

The result of research question one had it that nine strategies were accepted by students as being effective in the promotion of lifelong learning while one was rejected. By implication, this result suggests that provision of ICT facilities, provision of library facilities, award of scholarships to hardworking students, provision of medical services in schools, provision of laboratory and workshop facilities, provision of conducive classrooms, provision of conducive hostel accommodation, ensuring effective teaching by academic staff and provision of counseling services for students are strategies that could be adopted by tertiary institutions management to promote lifelong learning in tertiary institutions in Cross River State. However, provision of recreational facilities in schools was not deemed an effective promotion strategy. This finding is in line with the work of Etemeh (2013) who maintained that promoting lifelong education implies the provision of conditions that will facilitate learning in formal schools considering that each day gives birth to new challenges, problems and discoveries in the field of science and technology which have invariably altered the way in which certain tasks are carried out. This finding is also consistent with the work of Osaro (2014) who stated that promoting lifelong learning in Nigeria requires giving tertiary educational institutions a facelift in the area of infrastructure and instructional facilities, pedagogy, curriculum, general administration and manpower. This finding underscores the importance of provision and proper management of needed school plant and personnel for the promotion of lifelong learning. 
This finding also corroborates the work of Zuala (2012) who emphasized that lifelong learning could only be encouraged when administrators of tertiary institutions place more emphasis on proper management of personnel (teaching and non teaching staff),prudent management and utilization of funds for the establishment of a motivating teaching and learning environment and introduction of modern pedagogy.

The result of the hypothesis holds that there is no significant difference in the mean responses of undergraduate students of Federal and State tertiary institutions on the strategies that could be adopted by tertiary institutions management in the promotion of lifelong learning in Cross River State. This necessitated the acceptance of the null hypothesis and rejection of the alternate hypothesis. This implies that students of both Federal and State tertiary institutions do not differ in their opinion on the strategies to be adopted by management of tertiary institutions in the promotion of lifelong learning. The reason for the outcome of this hypothesis lies in the fact that students at all levels of education are only motivated to learn when they are well catered for. This finding therefore supports Mobola (2014) who stated that provision of the necessary facilities for teaching and learning is a proven source of motivation for individuals to want to continue to learn and explore the frontiers of knowledge in many fields of learning. This finding also aligns with Ahymeti (2010) who noted that a good library with well stocked up-to-date books, journals, periodicals and efficient information and communication technology (ICT) are essentials that enhance learning. Akuegwu (2014) remarked that provision of ICT facilities in schools will give students ample opportunity to search for information, practice what they have learnt, further explore ideas and topics, interact and actively engage in learning. The outcome of this hypothesis is also a pointer to the strategies that could be adopted by management of tertiary institutions to rekindle the hunger and quest for knowledge among the youths which according to Okiro (2012) is fast decreasing owing in part to the failure of school managers to create the motivation to learn by providing the necessary conditions for teaching and learning to thrive.

\section{CONCLUSION}

Based on the outcome of this study, it was concluded that undergraduate students of
Federal and State tertiary institutions share the same views on ways of managing tertiary institutions for promoting lifelong learning in Cross River State. Therefore, insofar as lifelong learning is concerned in Cross River State, the strategies identified in this study should be adopted by management of tertiary institutions for the promotion of lifelong learning in the State.

\section{RECOMMENDATIONS}

Based on the findings of this study, the following recommendations were made:

1. Tertiary institutions should periodically organize massive enlightenment campaigns and educate the citizens on the relevance of lifelong learning to both individuals and the society at large.

2. Tertiary institutions should introduce a compulsory short internship programme where students will be exposed to work experiences with the desire for lifelong learning.

3. Management of tertiary institutions should as a matter of urgency embark on the provision of functional ICT facilities in their various schools to aid students in learning.

4. Guidance and counseling services should be provided in tertiary institutions to cater for both undergraduates and prospective students personal and academic needs.

5. Government and non-governmental organizations should adequately fund tertiary institutions to ensure that necessary facilities needed for lifelong learning are not lacking in higher institutions.

\section{REFERENCES}

Ahymeti, A. A., 2010. Basic issues in Educational Management. Lagos: Talkon Global Services.

Akuegwu B. A., 2014. Quality Higher Education and sustainable development. In G.O Unachukwu and P.N Okorji (eds). Educational management. A skill building approach. Mimo: Rex Charles and Patrick.

Akuegwu, B. A., Ntukidem, P. J. and Jaja, G., 2011. Information and Communications 
Technology (ICT) Facilities' Utilization for Quality Instructional Service Delivery among University Lecturers in Nigeria. International Journal of Research in Arts and Social Sciences, 3, (1): 33-53.

Ebirim, P. U. and Mbaji, I. N., 2012. Promoting lifelong tertiary education for sustainable national transformation in Imo State, Nigeria. Nigeria Journal of Educational Administration and Planning. 12(1)103116.

Etemeh, O. 2013. Educational administration in Nigeria. Enugu: Ruana Educational Publishers.

European commission Director-General for Education and culture., 2002. European report on quality indicator of lifelong learning. Fifteen quality indicators. Report based on the work of working group on quality indicators.

Jackson, J. F., 2013. Perspectives on lifelong learning in Nigeria. Journal of Education and Development. 4, (4): 14-17.

Knapper, C. and Cropley, A. J., 2000. Lifelong learning higher education. U.S.A: Stylis Publishing Inc.

Mbagwu, F. O., 2013. Promoting lifelong learning through innovative adult and non-formal education. International Journal of Research in Arts and Social Science. 5, (1): 342-353. Retrieved on May 2, 2015 from http://academicexcellencesociety.co

$\mathrm{m}$

Mobola, O. O., 2012. Education for national integration: a focus on Nigeria. Paper presented at the conference of national association of secondary school proprietors. Enugu: Zodiac Hotels, February 17-19.

Nwankwo, A. O., 2014. History of education in Nigeria. Enugu: Tons and Tons.

Okiro, C., 2012. Effects of school factors on students' academic achievement in selected universities in south south geopolitical zone of Nigeria. Journal of Research and Counselling. 2, (1): 43-60.

Osaro, B., 2014. Education and national development. Calabar: Vons concepts.

Onwuamanam, G. O., 2005. Issues in Nigerian Education. Zaria: Abdulahi and Abdulahi Press Ltd.

PtBilduungsforshung 2012. Lifelong learning. Retrieved August 22, 2014 from http://www.bmbf.de/de/lebenslangeslerne n.php.

Rizvi, F. and Lingard, B. 2010. Globalizing education policy. New York: Routledge, Taylor and Francis Group

Zuala, P., 2012. Lifelong learning in developing countries. Port Harcourt: Davis Press Ltd. 